\title{
Ichthyofaunal Survey in Selected Freshwater Habitats in Camarines Sur, Philippines
}

\author{
MARK NELL C. CORPUZ \\ ORCID No. 0000-0002-2582-0772 \\ markcorpuz.120785@gmail.com
}

University of the Philippines Los Baños-Limnological Research Station College of Arts and Sciences, University of the Philippines Los Baños, College Laguna 4031, Philippines

VACHEL GAY V. PALLER

ORCID No. 0000-0002-7295-7288

vgvpaller@yahoo.com

University of the Philippines Los Baños, College

Laguna 4031, Philippines

\section{PABLO P. OCAMPO}

ORCID No. 0000-0003-3236-8793

ppocampo@yahoo.com

Animal Biology Division, Institute of Biological Sciences

College of Arts and Sciences, University of the Philippines Los Baños, College

Laguna 4031, Philippines

\begin{abstract}
Ichthyofaunal surveys were conducted in five aquatic habitats (Lake Bato, Agos River, Bagacay Falls, Lake Baao-Bula, and Pawili River) in Camarines Sur, Philippines to evaluate the diversity and distribution of freshwater fish assemblages. The study collected a total of 8,184 individuals comprising 29 species, 22 genera, and belonging to 14 families. The three most abundant groups, in order of importance were cichlids, cyprinids, and poeciliids. Overall, four fish species comprised $52 \%$ of the total abundance. These were Oreochromis niloticus
\end{abstract}


(Cichlidae), Glossogobius giuris (Gobiidae), Poecilia sphenops (Poeciliidae), and $P$. reticulata (Poeciliidae). In terms of richness, Gobiidae are the most dominant fish group (8 species). Except in Bagacay, Shannon-Weiner diversity indices ranged from 2.04 to 2.07 . Relatively high evenness indices and low dominance values were computed in the four sites. Fish densities were significantly different among the five studied areas (Friedman test: $\chi^{2}=43.06, P<0.01$ ). Bray-Curtis similarity analysis on abundance data clearly showed two clusters. Fairly high levels of similarity $(49.61 \%-62.81 \%)$ were observed in Baao, Bato, Pawili, and Agos, whereas Bagacay was apparently deviated from the rest. Environmental variables are fluctuating but still within the tolerable level. The survey revealed the established feral populations of introduced fish species in the four representative sites. Aquaculture operations and domestic effluents were observed to be the main key drivers of fish faunal change in the lake and stream habitats.

Keywords: Bato, Camarines Sur, diversity, fish survey, Gobiidae, native species

\section{INTRODUCTION}

There are few fish surveys conducted in the Philippines after the monumental works of Herre (1924, 1927, 1953), mainly due to the limited ichthyofaunal surveys after the post-war period. Much of the research done had been focused only on evaluating the biodiversity of most marine species as well as commercially important freshwater fishes in the Philippines. A number of studies on freshwater fish species, however, were taxonomical in nature that described several newly discovered Philippine fish species (Larson 2005; Cervancia and Kottelat 2007; Watanabe et al. 2009). Nevertheless, few ecological studies have been done for diminutive freshwater fishes due to the deficiency in current conservation status and data on many native/endemic taxa (IUCN 1999; BAS 2013). The implications of valuable native freshwater ichthyofaunas with no commercial value are not fully well-documented (Santiago et al. 2001; Paller et al. 2011).

Current conservation status of freshwater fish assemblage in major aquatic habitats in western part of Camarines Sur (CamSur), Philippines is poorly evaluated. Despite of the conservation and mitigation efforts for CamSur, the lake and stream ecology remains under the continued threats from different degree of anthropogenic pressures and habitat degradation. It is also worsen by lack of local awareness, and participatory protection on freshwater native fish 
assemblages. To the best of our knowledge, much of scientific and research endeavors in CamSur are bias towards commercially important fish species such as Mistichthys luzonensis (Soliman et al. 1998; Soliman and Sergio 2001), and Oreochromis niloticus (Cuvin-Aralar et al. 2012), whilst conservation studies for other indigenous diminutive freshwater fish species are apparently overlooked.

Fish assemblage structure is commonly used key bioindicator and descriptor of fisheries stability (Welcomme 1995), invasive alien species (Guerrero 2014), and ecological integrity of aquatic habitats at spatial and temporal scales (Zampella and Bunnell 1998; Uy 2008). Furthermore, several synthetic biological indices are commonly applied for the study of diversity and distribution of fish assemblages, mainly to evaluate the ecological health condition of aquatic habitats (Begon et al. 1996; Kwak and Peterson 2007; Paller et al. 2011, 2013).

Little is known on the current status and distribution of freshwater fish assemblages in CamSur, Philippines, particularly those thriving in Lake Bato, Lake Baao-Bula, Pawili River, Agos River, and Bagacay Falls. This study aimed to describe the spatial variation of freshwater fish assemblages, and to compare the diversity indices and environmental variables among the aforementioned aquatic habitats.

\section{MATERIALS AND METHODS}

\section{Studied Areas}

Fish species were inventoried in the five studied sites in western part of CamSur, Philippines representing two lakes, two streams, and one cataract (Fig. 1). (1) Lake Bato $\left(13^{\circ} 19^{\prime} \mathrm{N}, 123^{\circ} 21^{\prime} \mathrm{E}\right.$ near the center) is the seventh major lake in the country. It is a shallow eutrophic lake that recognized as the biggest, and one of the most important lakes in Bicol Region, Philippines in terms of size and economic benefits. It has a surface area that varies from $25 \mathrm{~km}^{2}$ to $60 \mathrm{~km}^{2}$ on dry and wet season, respectively. Its average depth is around $8 \mathrm{~m}$. (2) Agos River is a $4.3 \mathrm{~km}$-long stream $\left(13^{\circ} 20 \mathrm{~N}, 123^{\circ} 24^{\prime} \mathrm{E}\right)$ that fed Bato with water

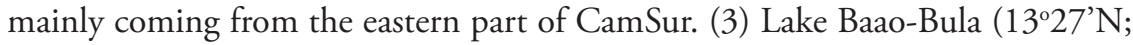
$123^{\circ} 18^{\prime} \mathrm{E}$ near the center) (hereafter denoted Baao) is also a shallow eutrophic freshwater lake, and known as phantom lake since it usually dries up during the dry months. It has an estimated surface area of $\left(1.77 \mathrm{~km}^{2}\right)$ and an average of only 1 meter deep. Pawili River $\left(13^{\circ} 31^{\prime} \mathrm{N}, 123^{\circ} 17^{\prime} \mathrm{E}\right)$ is a $4.7-\mathrm{km}$ long river that drains from urbanized Naga City and empties into the Baao. These four studied sites provide livelihood to the communities through aquaculture, fishing, 
irrigation, and tourism. Bagacay Falls is a semi-pristine cataract which has highly steep walls (about $6 \mathrm{~m}$ ) surrounded mostly by pristine portion of deciduous and riparian forest, and epiphytes. The presence of calcified marine biota remnants such as shells, bryozoans, and sponges suggest marine origin of the areas. The site offers eco-tourism.

\section{Sampling and Data Collection}

Sixteen sampling stations were selected in littoral zone of the two lakes, whilst twelve stations were sampled in the two streams. Unit area sampled in each station was approximately $80-100 \mathrm{~m}^{2}$. Three stations each having $60-80 \mathrm{~m}^{2}$ were selected in the pool zone, and riffle zone of Bacagay. Seine netting (dimension $=$ $8.0 \mathrm{~m} \times 1.0 \mathrm{~m}$, mesh size $=1.2 \mathrm{~mm} \times 1.2 \mathrm{~mm}$ ) was used in lakes and rivers with fine substrate, whereas 12-v backpack electrofishing gear was used in sites areas having rocky substrate. Seine nets and hand-nets were also used as traps during electro-fishing, wherein they were placed at the end of the transect lines to catch the fishes that goes with the water flow. Individual sampling run lasted ca. 40 min, and were done during day time (700-1500 hrs). Three-day sampling was carried out in February-March, and in July 2010. All species caught regardless of collection method used were initially counted, and identified at lowest possible taxon. Most of the captured fish were released alive back into the water. Captured fish were immediately counted and identified at lowest possible taxon. Specimens were either housed in laboratory as live specimens or preserved in $10 \%$ buffered formaldehyde for further documentation and identification. Specimens were identified using several fish identification materials (Herre 1924, 1927, 1953; Conlu 1986; Vidthayanon 2007; Froese and Pauly 2012).

Before collection, dissolved oxygen (DO, $\mathrm{mgl}^{-1}$, Hanna HI 3810), water temperature $\left({ }^{\circ} \mathrm{C}\right), \mathrm{pH}$ (Oakton $\mathrm{pH}$ tester 30$)$, and salinity $\left(\mathrm{mg} \mathrm{L}^{-1}\right.$, Atago hand refractometer) were recorded in each site. Geographic position was also recorded for each sampling station using a GPS device (CarNAVi Pro 400). Transparency $(\mathrm{cm})$ was measured using a Secchi disc in each sampling station. Mean depth (m) was measured using a Secchi disc for depth more than $1 \mathrm{~m}$, and a wooden ruler for depth less than $1 \mathrm{~m}$ at three points at each sampling station. Stream flow $\left(\mathrm{m} \mathrm{s}^{-1}\right)$ was measured using a simple float. Dominant bottom type was recorded and categorized as organic detritus, silt, mud, sand $(0.02-2.0 \mathrm{~mm})$, gravel $(2-64 \mathrm{~mm})$, cobble $(64-256 \mathrm{~mm})$, and boulder $(>256 \mathrm{~mm}$ ) (May \& Brown 2000). Visual estimation of vegetation cover (\%) was determined by the relative amount of submerged and floating hydrophytes to sampling path as well 
as those occupying both sides of the riverbanks at time of sampling. Land use pattern is categorized based on the characteristic of landscape surrounding the riparian zone.

\section{Data Analyses.}

Species richness was determined by the number of species present in a community. The relative abundance for each species was calculated as:

$$
\text { Relative abundance }=\left(\frac{\mathrm{a} i}{\mathrm{~A}}\right) 100 \%
$$

where: $a_{i}$ is the number of individuals collected in the ith species and $A$ is the total number of species collected. Diversity index was computed following the Shannon-Weiner diversity index (H') (Shannon \& Weaver 1949):

$$
\mathrm{H}^{\prime}=-\sum_{i=1}^{\mathrm{S}} p i \ln p i
$$

where: $s$ is the number of species; $\mathrm{p}$ is the proportion of individuals found in the ith species and $\ln$ is the natural logarithm. Evenness (J') was computed following the Shannon's diversity index:

$$
J^{\prime}=\frac{\mathrm{H}^{\prime}}{\ln \mathrm{S}}
$$

where: $\mathrm{S}$ is the total number of species. Species dominance was computed using the Simpson's index formula $(\lambda)$ (Simpson 1949):

$$
\lambda=\sum_{i=1}^{S} \frac{n i(n i-1)}{N(N-1)}
$$

where: $s$ is the number of species, $n_{\mathrm{i}}$ is the number of individuals in the ith species and $N$ is the total number of individuals. Fish densities (number of individuals collected in one species $/ 10 \mathrm{~m}^{2}$ ) were computed for each site. Cumulative fish density data did not follow the normality assumptions (Shapiro-Wilk test), and with that, Friedman test and Wilcoxon test (pairwise comparison) were employed to determine the median variation of pooled density among the studied sites $(P<$ $0.05)$.

Abundance data were $\log _{10}(x+1)$ transformed to linearize the relationship. 
Descriptive statistics of environmental variables were also computed. All variables did not meet the parametric assumptions and were subjected to univariate nonparametric tests (Kruskal-Wallis $H$-test, and Mann-Whitney $U$-test, $P<0.05$ ). Bray-Curtis Index (Bray and Curtis 1957) was used to measure the similarity between habitats and the unweight pair group method with arithmetic mean was used to classify the groups according to log-transformed abundance data. All statistical analyses were performed using Paleontological Statistic version 3.0 and Statistica version 7.0.

\section{RESULTS AND DISCUSSION}

\section{Environmental Data}

Environmental characteristics of the five studied sites are presented in Table 1. Significant spatial differences were recorded in DO levels $(P<0.05)$, with the highest, and lowest DO concentrations were recorded in Bagacay, and Baao, respectively. Levels of $\mathrm{pH}(7.74-8.47)$ were statistically varied among sites $(P<$ 0.01). Temperature was significantly comparable between Bato, Agos, Baao-Bula, and Pawili, but the temperatures of such were statistically different in Bagacay $(P<$ $0.01)$. Surface water current was statistically similar between the two streams $(P<$ 0.01 ), albeit considerably stronger current was measured in Bagacay. Freshwater conditions $(\leq 0.05 \mathrm{ppt})$ were recorded in all sites.

The observed fluctuation of water parameters can be attributed to the variation between habitat types (lacustrine vs. riverine environment). Likewise, physico-chemical parameters (particularly temperature) in each site varied only according to the time of the sampling day when the parameters were recorded. Increased aeration brought by the water current could be the contributory factor in the higher measured DO levels in studied streams and cataract. Although slightly variable, conditions of $\mathrm{pH}$ are fairly neutral to basic. Spatial variation on temperatures was likewise observed, with higher temperatures measured in lacustrine habitats as compared to representative streams and cataract. Nevertheless, the parameters are still within the tolerable range for the survival of tropical fishes (Boyd 1982).

\section{Abundance and Fish Composition}

Overall,the completed ichthyofaunal survey inventoried a total of 8,184 specimens belonging to 29 species, 22 genera, and 14 families (Table 2). Bato had the highest fish abundance $(n=2,633)$ followed by $\operatorname{Agos}(n=2,182)$, Baao-Bula 
( $n=1,412)$, Pawili $(n=1,400)$, and Bagacay $(n=557)$. Baao and an adjacent river Pawili had equal number of collected fish species (12 species). Bato had 20 species and its tributary Agos had 18 species. The isolated Bagacay had two enigmatic gobiids (Table 2 ). In terms of richness, gobiids ( 8 species), cyprinids (3 species), and poeciliids (3 species) are the most dominant fish species recorded in all sites. Gobiid was the most dominant fish group in Agos (5 species), Pawili (4 species), Bagacay (2 species), and Bato (jointly shared by cyprinids with 3 species each family), whereas cyprinids (3 species) are the most common fish group in Baao.

In general, four fish species comprised ca. $52 \%$ of the total abundance collected from the five studied sites. These were Oreochromis niloticus (Cichlidae), with relative abundance of $18.64 \%$, Glossogobius giuris (Gobiidae) 13.28\%, Poecilia sphenops (Poeciliidae) 10.82\%, and P. reticulata (Poeciliidae) 10.31\%. Two fish species comprised the $55.34 \%$ of the total abundance collected from Bato. These were $O$. niloticus, with relative abundance of $30.12 \%$, and G. giuris 25.22\%. The most abundant fish species in Agos were P. reticulata and $P$. sphenops (50.87\% of the cumulative relative abundance and in order of importance). Three fish species namely, Borbodes gonionotus (Cyprinidae), Leiopotherapon plumbeus (Terapontidae), and Cyprinus carpio (Cyprinidae) were the most abundant catch in Baao (57.36\%), whereas O. niloticus, C. carpio, and G. giuris in Pawili (55.36\%). In Bagacay, a single fish species Redigobius rivalis (Gobiidae) (99.38\%) dominated the total number of fish collected

The survey revealed that the introduced species mostly consisting of cichlids, cyprinids, and poeciliids are establishing feral populations in four representative sites. Introduced species documented in the current study are known to be habitat generalists, highly prolific, and can reduce fish diversity through competition with natives (Cagauan 2007, Guerrero III 2014). As suggested by Humpl and Pivnicka (2006), the abundance of introduced fish species is often attributed by their escaping from fish cages, and or by regular stocking by fish farmers.

Escapement of introduced cultured fish species and their potential to become invasive are considered to be the most detrimental effect of aquaculture on biodiversity loss (Diana 2009). It is widely known that their establishment and invasion success are mainly attributed for being highly adaptive to wide range of conditions and efficient resource acquisition in the environment (Burnett et al. 2006). In Bato, around 14,000 fish cages (mostly tilapia farming) are said to be operating in the lake, and the presence of these may negatively influence the lake and stream fish assemblages. One damaging impact of such is the recognized 
depletion of stock of the esteemed smallest commercial fish, M. luzonensis (Gobiidae) due to predation. Continuous agricultural run-offs and residential effluents also pose threats to the stability of more vulnerable native fish faunas. (Pili, Municipal Agriculturist of Bato, pers. comm.). A similar plight was also recognized in Baao. Although unlike in Bato, the local communities seem to be satisfied in the existing ichthyofaunal condition of the lake as the fisher folks otherwise desire the introduced species as the major components of their fish catch (Joven, Agricultural Officer of Baao, pers. comm.).

\section{Fish Diversity and Densities}

Biological indices and fish densities for each representative site were summarized in Table 3. Four studied sites namely, Bato, Agos, Baao, and Pawili exhibited relatively high diversity indices (2.04-2.07), while Bagacay was least diverse $(0.04, P<0.01)$. Shannon's Evenness for the aforementioned sites also showed relatively high values $(0.68-0.82)$, albeit the equitability indices of Bato and Agos were statistically different from those computed in Baao and Pawili $(P<$ 0.05). Bagacay had significantly lowest evenness value $(0.07, P<0.01)$.

Bagacay had a very high Simpson's dominance value (0.99), which was statistically different from the low dominance values $(0.15-0.18)$ of other four sites $(P<0.01)$. Pooled fish densities were significantly different among the five studied areas (Friedman test: $\chi^{2}=43.06, P<0.01$ ). Pairwise comparison revealed significant spatial differences except to fish densities recorded in Bato vs Bagacay (Wilcoxon test: $Z=1.63, P>0.05$ ), and Baao vs Pawili (Wilcoxon test: $Z=1.73$, $P>0.05)$.

In comparison, estimated H' (except Bagacay) was higher than any of those in the mountain streams in Mt. Makiling Forest Reserve in Laguna (mean richness $=12$, mean $H^{\prime}=1.16$ ) (Paller et al. 2011), and in Tayabas-Iyam streams of Mt. Banahaw Protected Lanscape in Quezon (mean richness $=13$, mean $\mathrm{H}^{\prime}=1.55$ ) (Paller et al. 2013). Our computed H', however, was comparatively lower than any of those measured in the streams in Sorsogon (richness $=16$, mean $H^{\prime}=$ 2.41), and Pansipit River in Batangas (richness $=21$, mean $H^{\prime}=3.05$ ) (Corpuz et al. 2010,2011). According to Namin and Spurny's (2004) method of categorizing the estimated H' values based on the impact of anthropogenic disturbances, the computed H' in Bato's lakes and streams are considered moderately impacted. The species distribution exhibited low dominance and relatively high evenness signifying that the allocation of niche space is distributed equitably for dominant 
and non-dominant fish species (Begon et al.1996), albeit a very high dominance of a single species was determined in Bagacay.

\section{Similarity}

Bray-Curtis similarity analysis for fish composition and log-transformed abundance data revealed the clustering of the five sites (Fig. 2). Bagacay registered nearly $0.00 \%$ level of similarity, which was clearly deviated from the other sites. Interestingly, relatively high levels of similarity were observed between Baao, Bato, Pawili, and Agos (in order of similarity) having a range of $49.61 \%-62.81 \%$. The overall ichthyofaunal resemblances among watersheds (except Bacagay) are relatively high as inferred by the occurrence of various introduced fish species $O$. niloticus, C. carpio, Trichopodus pectoralis, T. trichopterus, P. sphenops, P. reticulata, and a native species, $G$. celebius. Such fish species are the most common and widely distributed in the studied sites of CamSur. These similarities are associated to hydro-spatial connection of the four sites, dispersal mechanism of the fish, and or due to translocation and re-introduction during stocking of cultured species. Native fish species, however, had relatively low similarity (23.24\%), indicating the exclusivity of some species in a particular site (e.g. Anguilla marmorata,M. luzonensis, $R$. bikolanus, Leiognathus equulus, and Crenimugil heterocheilos in Bato, Gulaphallus bikolanus, and Dermogenys pusilla in Pawili). Interestingly, the pristine Bagacay served as sanctuary for only two gobiids, a riffle-dwelling $R$. rivalis and a pool-dwelling Stiphodon elegans. For this study, 6 out of 20 species were considered exclusive to Bato; 4 out of 18 species were exclusive to Agos; whereas fish species in Baao and Pawili are common inhabitants in Bato and Agos.

\section{CONCLUSIONS}

The four aquatic habitats namely: Bato, Agos, Baao, and Pawili had relatively diverse freshwater fishes, with true gobies (Gobiidae) being the most dominant group in terms of richness, albeit the fish abundance is numerically dominated by introduced or exotic fish species (cichlids, cyprinids, and poeciliids). The presence of introduced species, specifically, O. niloticus is attributed to escapement from fish pens and cages, and or introduction for aquaculture. In general, the areas are classified moderately impacted by anthropogenic pressures. Despite having a low diversity, the isolated and semi-pristine Bacagay provides haven for two enigmatic gobies. This study updated the list of freshwater fishes in CamSur, 
and provide essential baseline information for future fish survey and further conservation strategies for the studied areas.

\section{ACKNOWLEDGMENTS}

The authors are grateful for the funding of the Department of Science and Technology and Philippine Council for the Aquatic and Marine Research and Development through Fish Ark Philippines program; to the local government units of Bato, and Baao, Camarines Sur for allowing us to conduct our studies in their areas; to BV Labatos, OE Matalog, RR Alvarez, RL Willy, N Salvador, B Lontoc, and G Oldan for the technical and administrative supports during the survey; and to Bureau of Fisheries and Aquatic resources for the accommodation and logistic.

\section{LITERATURE CITED}

BAS[Bureau of Agricultural Statistics]

2013 Fisheries statistics of the Philippines 2008-2010. Quezon City, Department of Agriculture, 402p.

Begon, M.,J.L. Harper and C.R. Townsend

1996 Ecology: Individuals, Populations and Communities, $3^{\text {rd }}$ Ed. Blackwell Science, London, 1068p.

Boyd, C.E.

1982 Water quality management for pond fish culture. Elsevier Scientific Publishing Company. New York, USA, 318p.

Bray, J.R. and J.T. Curtis

1957 An ordination of the upland forest communities of Southern Wisconsin. EcolMonog 27: 325-349.

Burnett, K.M., B.A. Kaiser, B.A. Pitafi and J.A. Roumasset

2006 Prevention, eradication, and containment of invasive species: illustrations from Hawaii. Agri Res Econ Rev 35: 63-77. 
Cagauan, A.G.

2007 Exotic aquatic species introduction in the Philippines for aquaculture - a threat to biodiversity or a boom to the economy? J Environ Sci Manage 10: 48-62.

Cervancia, M. and M. Kottelat

2007 Cyclocheilichtys schoppeae, a new species of freshwater fish (Teleostei: Cyprinidae) from northern Palawan, Philippines. Raffles Bull Zool 55 (1): 141-145.

Corpuz, M.N., V.G. Paller, and P.P. Ocampo

2010 Ichthyofaunal survey in Bulusan Volcano Natural Park. Paper presented at the 14th Southern Luzon Zonal R \& D Symposium and Planning Workshop. Western Philippines University, Puerto Princesa City, Philippines.

Corpuz, M.N., V.G. Paller and P.P. Ocampo

2011 Diversity and distribution of freshwater fishes in Taal Lake river systems in Batangas, Philippines. Paper presented at the 15th Southern Luzon Zonal R \& D Symposium and Planning Workshop. Marinduque State College, Boac, Marinduque, Philippines.

Conlu, P.V.

1986 Guide to Philippine flora and fauna. Vol. IX - Fishes. Manila, Philippines: National Resources Management Center, Ministry of Natural Resources, and University of the Philippines.

Cuvin-Aralar, M.L., P. Gibbs, A. Palma, A. Andayog and L. Noblefranca

2012 Skip feeding as an alternative strategy in the production of Nile Tilapia Oreochromis niloticus (Linn.) in cages in selected lakes in the Philippines. Philipp Agric Sci 95 (4): 378-385.

Diana, J.S.

2009 Aquaculture production and biodiversity conservation. BioScience 59: $27-38$. 
Froese, R. and D. Pauly

2010 Fishbase. Electronic database accessible at http://www.fishbase.org. search. Updated on 12, February 2012.

Guerrero, III R.D.

2014 Impacts of introduced freshwater fishes in the Philippines (1905-2013): a review and recommendations. Phillip J Sci 143(1): 49-59.

Herre, A.H.

1924 Distribution of true freshwater fishes in the Philippines. Philipp J Sci 24 (3): $1-308$.

Herre, A.H.

1927 Gobies of the Philippines and the China Sea. Monog Bureau Sci 23: $1-352$.

Herre, A.H.

1953 A Checklist of Philippine Fishes. Research Report Vol. 20. Fish and Wildlife Service, United States Department of Interior, Government Publishing Office, Washington, DC, 977p.

Humpl, M. and K. Pivnicka

2006 Fish assemblages as influenced by environmental factors in streams in protected areas of the Czech Republic. Ecol Freshwater Fish15: 96-103.

IUCN [International Union for the Conservation of Nature]

1999 Red list of categories and criteria version. The World Conservation Union.Gland, Switzerland and Cambridge, UK, 242 p.

Kwak, T.J. and J.T. Peterson

2007 Community indices, parameters, and comparisons. In: Guy SC, Brown ML. (eds.). Analysis and Interpretation of Freshwater Fisheries Data. American Fisheries Society. Bethesda, Maryland. 961: 677-763.

Larson, H.K.

2005 A revision of the gobiid genus Stigmato gobius (Teleostei: Gobiidae), with descriptions of two new species. Ichthyol Explor Freshwaters 


$$
\text { 16(4): 347-370. }
$$

May, J.T. and L.R. Brown

2000 Fish community structure in relation to environmental variables within the Sacramento River basin and implications for the Greater Central Valley, California. US Geological Survey Report 00-247. Sacramento, California, 25p.

Namin, J.I. and P. Spurny

2004 Fish community structure of the middle course of the BecvaRiver. Czech J AnimSci 49(1): 43-50.

Paller,V.G., B.V. Labatos, B.M. Lontoc, O.E. Matalog and P.P. Ocampo 2011 Freshwater fish fauna in watersheds of Mt. Makiling Forest Reserve, Laguna, Philippines. Philippi J Sci140(2): 195-206.

Paller, V.V., M.C. Corpuz and P.P. Ocampo

2013 Diversity and distribution of freshwater fish assemblages in Tayabas River, Quezon (Philippines). Philipp J Sci142: 55-67.

Santiago, C.B., M.L. Cuvin-Aralar and ZU Basiao

2001 Proceedings of the national seminar-workshop on the conservation and ecological management of Philippine lakes in relation to fisheries and aquaculture. SEAFDEC Aquaculture Department, Tigbauan, Iloilo; Philippine Council for Aquatic and Marine Research and Development, Los Baños, Laguna; and Bureau of Fisheries and Aquatic Resources Quezon City, Philippines, 187p.

Shannon, C.E. and W. Weaver

1949 The Mathematical Theory of Communication. Urbana, Univ. Illinois Press, 117p.

Simpson, E.H.

1949 Measurement of diversity. Nature 163: 688.

Soliman, V.S., S.C. de Jesus and M.F. Sergio

1998 Biology and population dynamics of "Sinarapan" (Mistichthys luzonensis 
Smith). Paper presented on Symposium on the Biology and Management of Sinarapan (Mistichthys luzonensis Smith).

Soliman, V.S. and M.F. Sergio.

2001 Managing 'Sinarapan' Mistichthys luzoniensis Smith in Lake Buhi, Camarines Sur: insights from its biology and population dynamics. In: Santiago, C.B.,M.L. Cuvin-Aralar and Z.U.Basiao(eds.). Proceedings of the national seminar-workshop on the conservation and ecological management of Philippine lakes in relation to fisheries and aquaculture. SEAFDEC, PCAMRD and BFAR, Philippines 187p.

Uy, W.H.

2008 Coastal Biodiversity: implications of the BRP research on impact, vulnerability and adaptation to climate change. Paper presented at the International conference-workshop on biodiversity and climate change in Southeast Asia: adaptation and mitigation. Sofitel Philippine Plaza, Manila.

Watanabe, S., J. Aoyama and K.Tsukamoto

2009 A new species of freshwater eel Anguilla luzonensis (Teleostei: Anguillidae) from Luzon Island of the Philippines. Fish Sci (Tokyo) 75: 387-392.

Welcomme, R.L.

1995 Relationships between fisheries and the integrity of river systems. Regulated rivers: research and management 11: 121-136

Vidthayanon, C.

2007 Overview on freshwater fishes of the Philippines. Lecture presented during National training course on freshwater fish identification, 18 October 2007, SEARCA. Zonal Center 2 PCAMRD, IBS-UPLB, PIBCFI, Chester Zoo \&WorldFish Center, 1-8 p.

Zampella, R.A. and J.F. Bunnell

1998 Use of reference-site fish assemblages to assess aquatic degradation in pinelands streams. Ecol Appl 8: 645-658 
Table 1. Abiotic (mean \pm SE) and habitat characteristics of five studied sites in Bato, Camarines Sur, Philippines

\begin{tabular}{|c|c|c|c|c|c|c|}
\hline $\begin{array}{l}\text { Abiotic and Hab- } \\
\text { itat Characters }\end{array}$ & Bato & Agos & Bagacay & Baao & Pawili & $H$-values \\
\hline $\begin{array}{l}\text { Dissolved Oxygen } \\
\qquad\left(\mathrm{mg} \mathrm{L}^{-1}\right)\end{array}$ & $5.66 \pm 1.02^{\mathrm{ab}}$ & $6.38 \pm 1.54^{\mathrm{abc}}$ & $7.41 \pm 0.37^{c}$ & $5.22 \pm 0.57^{\mathrm{a}}$ & $6.15 \pm 0.15^{\mathrm{b}}$ & $9.91^{*}$ \\
\hline $\mathrm{pH}$ & $8.47 \pm 0.22^{\mathrm{a}}$ & $7.82 \pm 0.26^{\mathrm{b}}$ & $8.1 \pm 0.36^{a}$ & $7.74 \pm 0.55^{\mathrm{b}}$ & $7.75 \pm 0.18^{b}$ & $16.76^{* *}$ \\
\hline $\begin{array}{l}\text { Water Tempera- } \\
\text { ture }\left({ }^{\circ} \mathrm{C}\right)\end{array}$ & $29.28 \pm 0.85^{a}$ & $28.56 \pm 1.73^{\mathrm{a}}$ & $25.53 \pm 0.15^{b}$ & $29.59 \pm 1.28^{\mathrm{a}}$ & $27.93 \pm 1.10^{\mathrm{a}}$ & $15.39^{* *}$ \\
\hline $\begin{array}{c}\text { Surface } \\
\text { Velocity }\left(\mathrm{m} \mathrm{s}^{-1}\right)\end{array}$ & - & $0.49 \pm 0.09^{\mathrm{a}}$ & $0.98 \pm 0.13^{\mathrm{b}}$ & - & $0.47 \pm 0.07^{\mathrm{a}}$ & $12.52^{* *}$ \\
\hline Transparency $(\mathrm{cm})$ & $\begin{array}{c}28.78 \pm \\
0.74^{\mathrm{ab}}\end{array}$ & $30.56 \pm 0.97^{\mathrm{b}}$ & $43 \pm 0.84^{c}$ & $26.89 \pm 0.86^{a}$ & $29.67 \pm 0.83^{b}$ & $18.25^{* *}$ \\
\hline Depth (m) & $0.97 \pm 0.07^{\mathrm{a}}$ & $0.56 \pm 0.04^{c}$ & $0.52 \pm 0.08^{c}$ & $0.72 \pm 0.04^{\mathrm{b}}$ & $0.56 \pm 0.03^{c}$ & $26.17^{* *}$ \\
\hline Salinity $\left(\mathrm{mg} \mathrm{L}^{-1}\right)$ & 0.01 & 0.0 & 0.0 & 0.0 & 0.0 & - \\
\hline Substrata & $\begin{array}{l}\text { muddy }+ \\
\text { sandy }\end{array}$ & Sandy & $\begin{array}{c}\text { Boulder + } \\
\text { Cobble + } \\
\text { Sandy }\end{array}$ & Muddy & $\begin{array}{l}\text { Sandy + } \\
\text { cobble }\end{array}$ & - \\
\hline $\begin{array}{l}\text { Dominant vegeta- } \\
\text { tion }\end{array}$ & $\begin{array}{c}\begin{array}{c}\text { Eichhornia } \\
\text { crassipes, ri- } \\
\text { parian macro- } \\
\text { phytes }\end{array} \\
\end{array}$ & $\begin{array}{c}\text { riparian } \\
\text { macrophytes }\end{array}$ & $\begin{array}{l}\text { bryophytes, } \\
\text { epiphytes, } \\
\text { algae }\end{array}$ & $\begin{array}{c}\text { Oryza sativa, } \\
\text { riparian mac- } \\
\text { rophytes, } \\
\text { algae } \\
\end{array}$ & $\begin{array}{c}\text { riparian mac- } \\
\text { rophytes }\end{array}$ & - \\
\hline Land use & $\begin{array}{l}\text { residential, } \\
\text { agriculture }\end{array}$ & $\begin{array}{l}\text { grassland, } \\
\text { agriculture, } \\
\text { residential }\end{array}$ & forest & agriculture & $\begin{array}{l}\text { grassland, } \\
\text { agriculture }\end{array}$ & - \\
\hline
\end{tabular}

** significant at $1 \%$ level of confidence; *significant at $5 \%$ level of confidence; for each abiotic variable, means with same superscript letter are not significantly different at $5 \%$ level of confidence 
Table 2. Distribution of freshwater fish species recorded from the five studied sites in Bato, CamSur, Philippines

\begin{tabular}{|l|c|c|c|c|c|}
\hline \multicolumn{1}{|c|}{ Fishes } & Bato & Agos & Bagacay & Baao & Pawili \\
\hline Anguilidae (freshwater eels) & & & & & \\
\hline Anguilla marmorata & + & - & - & - & - \\
\hline Gobiidae (true gobies) & & & & & \\
\hline Glossogobius celebius & + & + & - & - & + \\
\hline Glossogobius giuris & + & - & - & + & + \\
\hline Mistichthys luzonensis & + & - & - & - & - \\
\hline Redigobius bikolanus & - & + & - & - & - \\
\hline Redigobius dispar & - & + & - & - & + \\
\hline Redigobius rivalis & - & - & + & - & - \\
\hline Rhinogobius sp. & - & + & - & - & + \\
\hline Stiphodon sp. & - & + & + & - & - \\
\hline Hemiramphidae (halfbeaks) & & & & & \\
\hline Dermogenys pusilla & - & + & - & - & - \\
\hline Zenarchopterus sp. & + & - & - & - & + \\
\hline Leiognathidae (slipmouths) & & & & & \\
\hline Leiognathus equulus & + & - & - & - & - \\
\hline Mugiliidae (mullets) & & & & & \\
\hline Crenimugil heterocheilos & + & - & - & - & - \\
\hline Phallosthetidae (priapium fishes) & & & & & \\
\hline Gulaphallus bikolanus & - & + & - & - & - \\
\hline Terapontidae (grunters) & & & & & \\
\hline Leiopotherapon plumbeus & + & + & - & + & + \\
\hline Anabantidae (climbing gouramis) & & & & & \\
\hline Anabas testudineus & + & - & - & - & - \\
\hline Channidae (murrels) & & & & & \\
\hline Channa striata & + & + & - & + & - \\
\hline Cichlidae (cichlids) & + & & & & \\
\hline Oreochromis niloticus & + & - & + & + \\
\hline Tilapia zillii & - & - & - & - \\
\hline
\end{tabular}




\begin{tabular}{|l|c|c|c|c|c|}
\hline Clariidae (freshwater catfishes) & & & & & \\
\hline Clarias batrachus & + & + & - & + & + \\
\hline Clarias gariepinus & - & + & - & + & - \\
\hline $\begin{array}{l}\text { Cyprinidae (cyprinids and } \\
\text { minnows) }\end{array}$ & & & & & \\
\hline Ctenopharyngodon idella & + & - & - & + & - \\
\hline Borbodes gonionotus & + & - & - & + & + \\
\hline Cyprinus carpio & + & + & - & + & + \\
\hline Osphronemidae (gouramis) & + & & & & \\
\hline Trichopodus pectoralis & + & + & - & + & - \\
\hline Trichopodus trichopterus & + & + & - & + & - \\
\hline Poecilidae (livebearers) & & & & & \\
\hline Xiphophorus hellerii & - & + & - & - & - \\
\hline Poecilia reticulata & + & + & - & - & + \\
\hline Poecilia sphenops & + & + & - & + & + \\
\hline Abundance & 2,633 & 2,182 & 557 & 1,412 & 1,400 \\
\hline
\end{tabular}

Table 3. Number of taxa, and diversity indices recorded from five studied sites in Camarines Sur, Philippines. H'= Shannon-Weiner diversity index; J'= Shannon evenness Index; $\lambda=$ Simpson's species dominance index; $d=$ fish density $\left(\right.$ fish $\left./ 10 \mathrm{~m}^{2}\right)$.

\begin{tabular}{|c|c|c|c|c|c|}
\hline $\begin{array}{c}\text { Biological } \\
\text { indices }\end{array}$ & Bato & Agos & Bagacay & Baao & Pawili \\
\hline Taxa & 20 & 18 & 2 & 12 & 12 \\
\hline$H^{\prime}$ & $2.06^{\mathrm{a}}$ & $2.05^{\mathrm{a}}$ & $0.04^{\mathrm{b}}$ & $2.07^{\mathrm{a}}$ & $2.04^{\mathrm{a}}$ \\
\hline$J^{\prime}$ & $0.68^{\mathrm{a}}$ & $0.72^{\mathrm{a}}$ & $0.07^{\mathrm{c}}$ & $0.83^{\mathrm{b}}$ & $0.82^{\mathrm{b}}$ \\
\hline$\lambda$ & $0.18^{\mathrm{a}}$ & $0.17^{\mathrm{a}}$ & $0.99^{\mathrm{b}}$ & $0.15^{\mathrm{a}}$ & $0.15^{\mathrm{a}}$ \\
\hline$d$ & 12 & $16-17$ & $12-13$ & 8 & $7-8$ \\
\hline
\end{tabular}

In a row, means with same superscript letter are not significantly different $(P>0.05)$ 

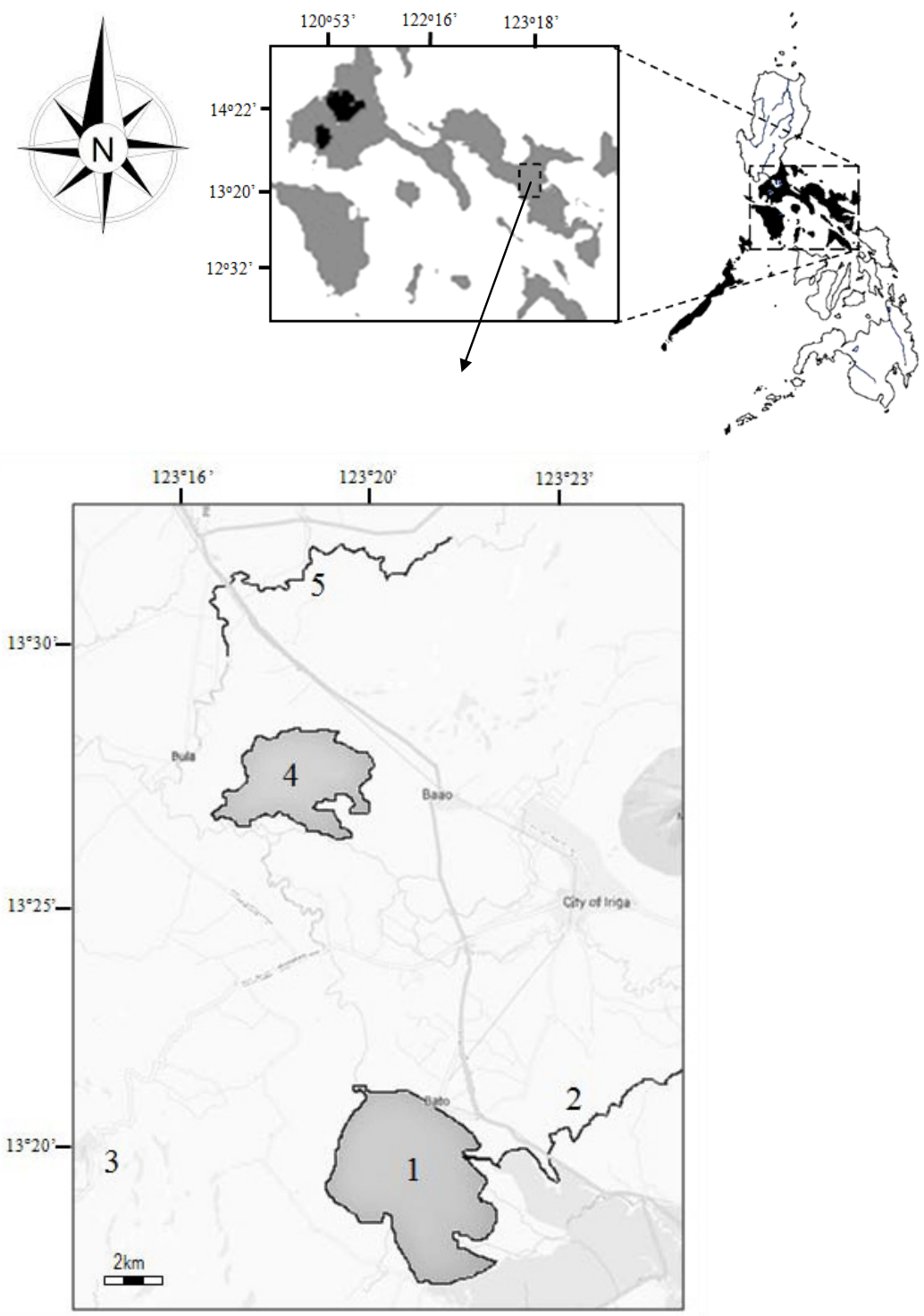

Fig. 1. Map of southern Luzon, Philippines showing the five studied sites.

(1) Lake Bato, (2) Agos River, (3) Bagacay Falls, (4) Lake Baao-Bula, and (5) Pawili River. 


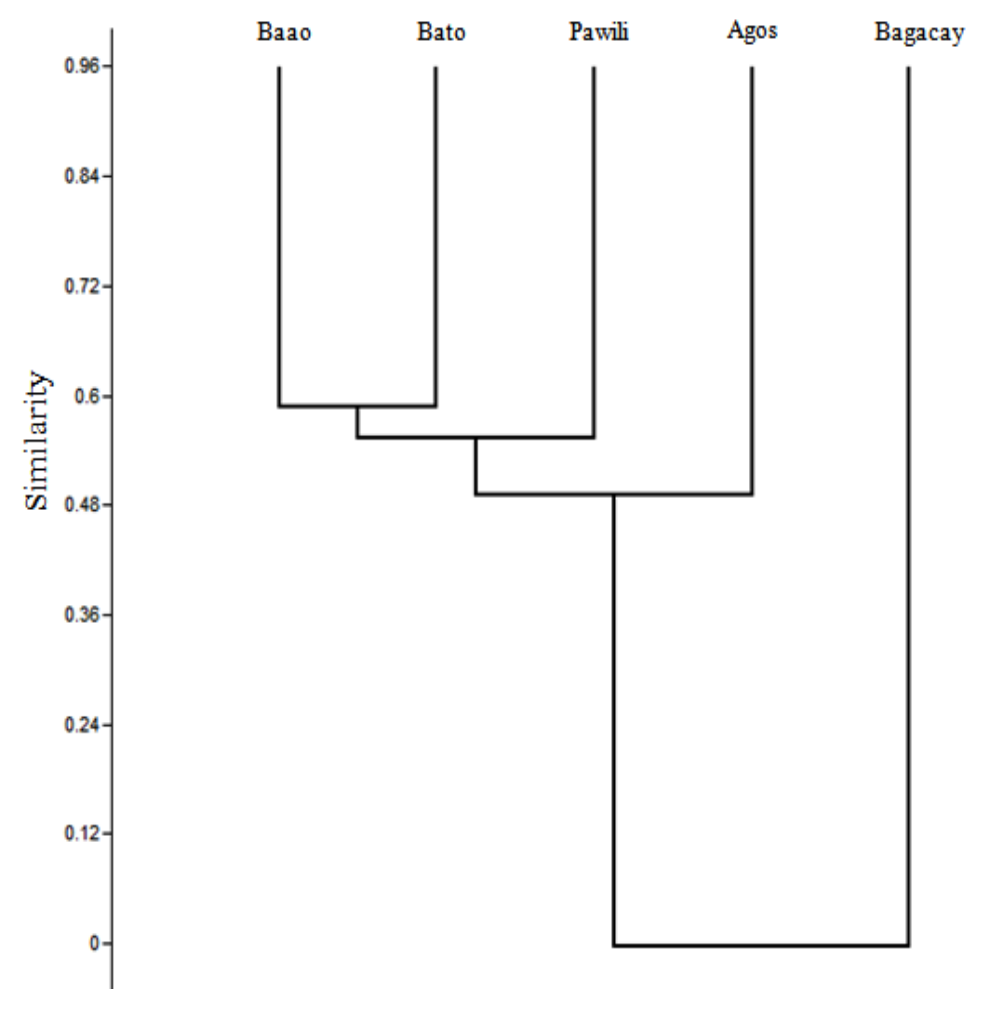

Fig. 2. A dendrogram from unweighted pair group method with arithmetic mean showing the relationship of five studied sites based on species composition and log-transformed abundance data. 


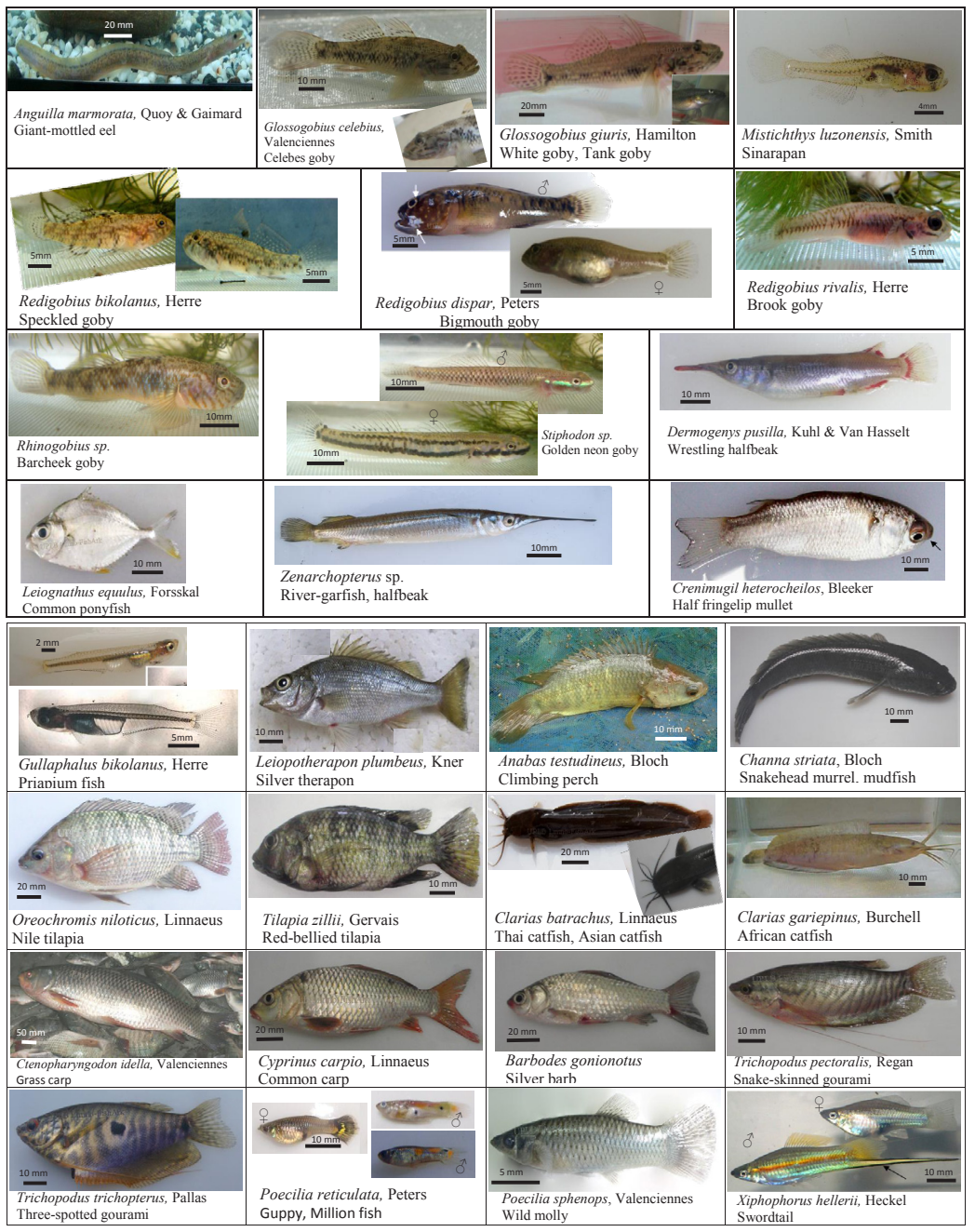

Plate 3. Photos, scientific names, and common names of freshwater fishes recorded from the five studied sites in Bato, CamSur, Philippines. 